\title{
Väkirehun koostumus ja intensiteetti hereford-sonnien loppukasvatuksessa b) Veren koostumuksen muutokset kasvatuksen aikana
}

Reeta Pösö ${ }^{1)}$, Ninna Koho ${ }^{1)}$, Merja Manninen ${ }^{2)}$ ja Lauri Jauhiainen ${ }^{2)}$

${ }^{1)} H Y, 00014$ Helsingin yliopisto, reeta.poso@helsinki.fi,ninna.koho@helsinki.fi

${ }^{2)}$ MTT, 31600 Jokioinen, merja.manninen@mtt.fi, lauri.jauhiainen@mtt.fi

\section{Johdanto}

Tämä tutkimus liittyy suurempaan kokonaisuuteen, jossa on selvitetty monipuolisesti miten vapaa väkirehuruokinta vaikuttaa lihanautojen hyvinvointiin, sorkkaterveyteen, eläimistä saatavan lihan laatuun ja tuotannon talouteen.

\section{Aineisto ja menetelmät}

\section{Eläinaines ja tuotanto-olosuhteet}

Kokeessa oli mukana 32 keväällä 2001 syntynyttä sonnivasikkaa, jotka kokeen alkuun saakka olivat emineen laitumella eivätkä saaneet väkirehua. Kokeen alkaessa vasikat olivat keskimäärin 6.7 kuukauden ikäisiä ja $307 \mathrm{~kg}$ painoisia. Koe tehtiin MTT:n emolehmänavetalla, jossa sonnit olivat 4 eläimen karsinoissa. Karsinoiden kuivituksen aikana sonnit ulkoilivat jaloittelutarhassa. Painon kehitystä seurattiin punnitsemalla eläimet säännöllisin väliajoin.

\section{Rehut ja ruokinta}

Koemalli oli $2 * 2$ faktoriaalinen, faktoreina väkirehutyyppi (kotiseos, K vs. täysrehu, T) ja loppukasvatuksen väkirehuintensiteetti (rajoitettu (3 kg/vrk), R vs. vapaa, V). Kotiseos oli jauhettu kaura-ohrarypsirouhe-seos. Väkirehun lisäksi kaikki eläimet saivat nurmisäilörehua ja vettä vapaasti. Rehujen koostumus ja ruokinta on selostettu tarkemmin tämän koesarjan ensimmäisessä raportissa (Tuotanto ja ruohon laatu).

\section{Näytteenotto ja näytteiden käsittely}

Kaikki verinäytteet otettiin kaulalaskimosta. Näytteet otettiin kaikista eläimistä kokeen alkaessa 9.10, loppukasvatusjakson alkaessa 25.2, loppukasvatusjakson puolivälissä 8.4 sekä päivänä, jolloin ensimmäinen ryhmä teurastettiin (29.4). Tämän lisäksi kustakin ryhmästä otettiin verinäyte teurastusaamuna navetassa. Eläinten lukumäärät teurastuspäivittäin olivat 7 (29.4), 5 (13.5), 7 (27.5), 6 (10.6) ja 7 (17.6).

Osa verestä siirrettiin putkeen, jossa oli $0.6 \mathrm{M}$ perkloorihappoa, ja loput sentrifugoitiin ja seerumi pakastettiin. Myös perkloorihappoputket pakastettiin. Perkloorihapponäytteistä määritettiin $\beta$ hydroksivoihapon ja glukoosin pitoisuudet. Seeruminäytteistä analysoitiin natrium, kalium, kloridi, kalsium, kokonaisproteiini, glyseroli, vapaat rasvahapot ja urea sekä gammaglutamyylitranspeptidaasin (GGT) aktiivisuus. Määritykset tehtiin Helsingin yliopiston eläinlääketieteellisen tiedekunnan keskuslaboratoriossa käyttäen laboratorion rutiinimenetelmiä.

\section{Tilastollinen käsittely}

Eläimet jaettiin koon mukaan kahteen lohkoon ja kummankin lohkon sisällä eläimet arvottiin neljään karsinaan, joihin kuhunkin kohdistui yksi käsittelyistä. Tilastollisessa käsittelyssä muuttujina olivat rehu, aika ja rehun intensiteetti. Analyysit suoritettiin SAS:n (1999) versiolla 8.2.

\section{Tulokset ja tulosten tarkastelu}

Seerumista mitatuissa arvoissa näkyi muutoksia sekä ennen loppukasvatusta, että loppukasvatusjakson aikana. Ennen loppukasvatusta muutokset olivat samankaltaisia kaikissa eläimissä, mutta loppukasvatuksen aikana nähtiin myös ryhmien välisiä eroja. Tuloksista on tässä esitetty ainoastaan ne loppukasvatuksen aikana tapahtuneet muutokset, joissa vapaan ja rajoitetun ruokinnan välillä oli tilastollisesti merkittäviä eroja. 
Seerumin natrium- ja kloridipitoisuuksissa ei tapahtunut mitään muutoksia ajan suhteen, mutta KVryhmässä kloridipitoisuus oli korkeampi verrattuna KR-ryhmään loppukasvatusjakson puolivälissä. Kaliumpitoisuudet laskivat kokeen alusta loppukasvatusjakson puoliväliin KV-ryhmää lukuun ottamatta kaikissa ryhmissä. Kalsiumpitoisuus laski kaikissa ryhmissä loppukasvatusjakson alusta jakson puoliväliin ja pysyi sitten tällä alentuneella tasolla kokeen loppuun saakka. Muutoksista huolimatta kaikki mitatut arvot olivat normaaliarvojen rajoissa.

Maksan toimintaa kuvaavia parametreja olivat proteiini, urea ja GGT. GGT:n aktiviisuus kohosi kokeen alusta kaikissa ryhmissä, mutta ruokinnan intensiteetti tai rehun koostumus eivät vaikuttaneet muutokseen. Ureapitoisuudessa rehun intensiteetti x aika yhdysvaikutus oli tilastollisesti merkitsevä. Kaikissa ryhmissä ureapitoisuus väheni kokeen alusta loppukasvatusjakson alkuun. Tämän jälkeen ureapitoisuus kohosi merkitsevästi vapaasti ruokituissa ryhmissä, mutta jatkoi alenemista ryhmissä, joissa väkirehun saanti oli rajoitettua. Kaikissa ryhmissä loppukasvatusjakson jälkimmäisellä puoliskolla ei enää tapahtunut merkitseviä muutoksia seerumin ureapitoisuuksissa. Loppukasvatusjakson puolivälissä seerumin kokonaisproteiinipitoisuus oli merkitsevästi korkeampi kuin rajoitetulla ruokinnalla olleissa sonneissa. Tässä pisteessä proteiinipitoisuuden ja ureapitoisuuden välillä vallitsi positiivinen korrelaatio ( $\mathrm{r}=0.547$; $\mathrm{p}<0.01)$.
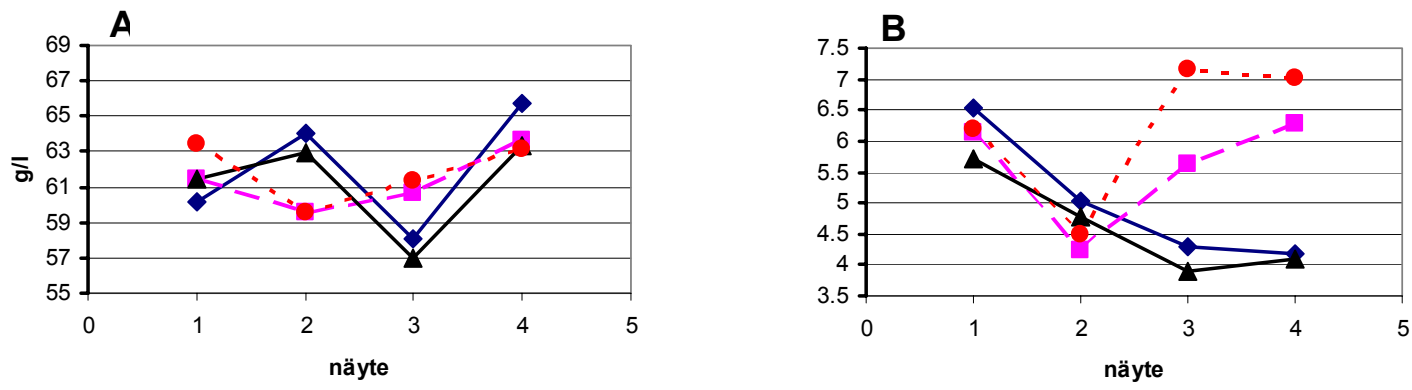

Kuva 1. Seerumin kokonaisproteiinipitoisuuden (A) ja ureapitoisuuden (B, mmol/l) muutokset sonnien kasvatuskokeen aikana. Rajoitetulla ruokinnalla olleet ryhmät on esitetty yhtenäisillä viivoilla (vinoneliö = kotiseos; kolmio $=$ täysrehu) ja vapaalla ruokinnalla olleet ryhmä katkoviivoilla (neliö = kotiseos; pallo $=$ täysrehu). Arvot ovat ryhmien keskiarvoja.

Rasva-aineenvaihduntaa kuvaavat glyseroli, vapaat rasvahapot sekä $\beta$-hydroksivoihappo ja hiilihydraattiaineenvaihduntaa veren glukoosi. Vapaiden rasvahappojen määrä veressä nousi loppukasvatusjakson puoliväliin ja pysyi sen jälkeen muuttumattomana. Koti- ja kaupallisen rehun välillä oli merkittävä ero loppuruokintajakson puolivälissä, mutta ei enää jakson lopussa. Glyseroli muutokset heijastivat vapaiden rasvahappojen muutoksia ja näiden kahden parametrin välillä oli positiivinen korrelaatio $(r=0.577 ; \mathrm{p}<0.001)$ kokeen lopussa. $\beta$-hydroksivoihapon muutokset olivat käänteisiä vapaiden rasvahappojen muutoksille. Kokeen alusta pitoisuus aleni loppukasvatusjakson puoliväliin saakka, jonka jälkeen rajoitetulla ruokinnalla olleiden sonnien pitoisuudet kohosivat, mutta säilyivät muuttumattomana vapaasti ruokitussa ryhmässä. Näin ollen kokeen lopussa rehun intensiteetin mukaan ryhmien välillä oli tilastollisesti merkitsevä ero. Glukoosipitoisuudet kohosivat rajoitetulla ruokinnalla olleissa eläimissä loppuruokintajakson puolivälistä jakson loppuun, kun taas vapaasti ruokituissa sonneissa ei koko kokeen aikana tapahtunut mitään merkittäviä muutoksia veren glukoosipitoisuuksissa. 

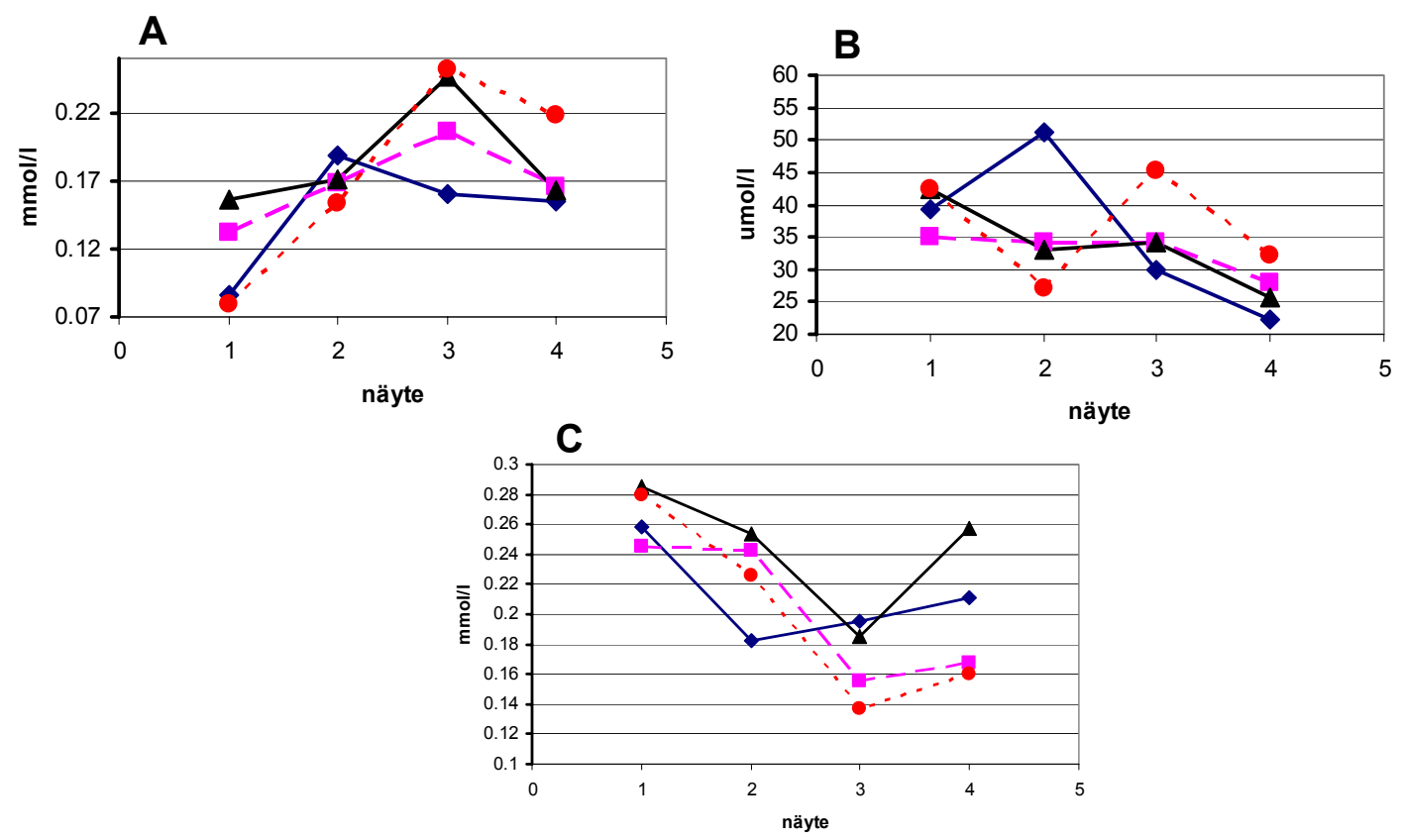

Kuva 2. Rasva-aineenvaihduntaa kuvaavien vapaiden rasvahappojen (A), glyserolin (B) ja $\beta$ hydroksivoihapon (C) pitoisuudet sonnien kasvatuskokeen aikana. Tulokset on esitetty keskiarvoina symbolit ovat samat kuin kuvassa 1.

\section{Johtopäätökset}

Vapaa väkirehuruokinta vaikutti merkittävästi seerumin kokonaisproteiini- ja ureapitoisuuksiin. Kokonaisproteiinipitoisuudessa vaikutus oli ohimenevä, mutta ureapitoisuudet pysyivät koholla kokeen loppuun saakka. Ureapitoisuuden nousu heijastaa eläinten syömän valkuaisen määrää ja tai ureakierron aktiivisuutta. Mikäli eläin saa ravinnostaan enemmän aminohappoja kuin mitä se pystyy käyttämään valkuaisainesynteesiin, on aminohappojen ylimäärä käytettävä energiaksi, koska valkuaisaineille ei ole olemassa varastomuotoa glykogeenin ja tri-glyseridien tapaan. Tämän verran kohonneista ureapitoisuuksista ei ole eläimelle mitään terveydellistä haittaa, pikemminkin haittana on virtsaan erittyvän typen määrän lisääntyminen ja sitä kautta ympäristön kuormittuminen. Vaikka muutokset gammaglutamyylitranspeptidaasissa eivät olleetkaan tilastollisesti merkittäviä, oli tuloksissa havaittavissa, että vapaalla ruokinnalla olleissa eläimissä arvot kasvoivat koko ruokintajakson ajan. Tätä ilmiötä ei havaittu rajoitetulla ruokinnalla olleissa eläimissä. GGT indikoi maksan hyvinvointia, joten havaittu suuntaus kertoo, että aminohappoylimäärä rasittaa maksaa ja pitempikestoinen vapaa väkirehuruokinta saattaa aiheuttaa maksan toimintahäiriöitä. Tulokset osoittavat myös, että seerumin ureapitoisuuden seuraaminen saattaa olla hyödyllistä arvioitaessa optimaalista valkuaisainetarvetta.

Pelkästään näiden tulosten perusteella ei pystytä selvittämään, miksi rasva-aineenvaihduntaan liittyvissä parametreissa oli eroja verrattaessa vapaalla väkirehuruokinnalla olleita rajoitetulla ruokinnalla olleisiin. Tutkimuksessa ei löytynyt korrelaatiota lipolyysiä indikoivien vapaiden rasvahappojen ja glyserolin sekä stressiä indikoivien lämpösokkiproteiinien ja kortisolin välillä.

Kiitokset Rehuraisio Oy:lle kokeeseen toimitetusta täysrehusta sekä MTT:n emolehmänavetan ja Kiteen opetusteurastamon henkilökunnalle hyvin sujuneesta yhteistyöstä. 